\title{
水理模型実験におけるハイドロフォンを用いた 流砂量計測 \\ MEASUREMENT OF BED LOAD USING HYDROPHONES IN HYDRAULIC MODEL EXPERIMENTS
}

\author{
小田 晃 ${ }^{1} \cdot$ 長谷川祐治 $^{2} \cdot$ 水山高久 $^{3} \cdot$ 野中理伸 $^{4} \cdot$ 宮本邦明 ${ }^{5}$ \\ Akira ODA, Yuji HASEGAWA,Takahisa MIZUYAMA,Michinobu NONAKA and Kuniaki MIYAMOTO \\ ${ }^{1}$ 正会員 博士（工）（財）建設技術研究所 筑波試験所（テ 300-2633 茨城県つくば市遠東 904-1） \\ 2 正会員 工修 （財）建設技術研究所 筑波試験所（テ300-2633 茨城県つくば市遠東 904-1） \\ ${ }^{3}$ 正会員 農博 京都大学大学院教授 農学研究科森林科学専攻（T606-8502 京都府京都市左京区北白川追分町） \\ 4 (株) ハイドロテック（テ529-1642 滋賀県蒲生郡日野町上野田 876) \\ 5 正会員 工博 筑波大学助教授 農林工学系（テ305-8572 茨城県つくば市天王台 1-1-1）
}

\begin{abstract}
Recently, in order to obtain basic data for the integrated management of the sediment transport in a river basin, several monitoring of the bed load by indirect estimation in actual rivers called the hydrophone method have been conducted and examined for practical use. In hydraulic model experiments to evaluate the function and efficiency of installing sabo facilities in rivers, the bed load is measured by trapping directly the sediment using boxes, sieves, etc.

In the present study, we measured the temporal variations of pulse counts reflected from collisions the sediment particles with the various shapes of hydrophones which are laid in a rectangular channel. We then compared the results of the measurement of bed load at the downstream end of the geometric model by means of hydrophones with those obtained from the conventional way of measuring bed load by using sieve. As a result, it has been confirmed that the results of actually measured bed load are in good agreement with those obtained from pulses by mean of hydrophones and therefore that hydrophone is indeed applicable to hydraulic model experiments.
\end{abstract}

Key Words : bed load, hydrophone, measurement, hydraulic model experiment, pulse

\section{1.はじめに}

近年，水系一貫した土砂管理を目的として実際の河川 における流砂量のモニタリングが各地で試験的に実施さ れている ${ }^{124)}$. その中で, 河床に設置した金属管に流砂が 衝突する際に発する音響パルス数から流砂量を間接的に 推定する方法 (ハイドロフォン流砂計測法) が開発され 1)，実用化に向けて検討が行われている ${ }^{428)}$.

一方，河川・砂防施設の配置計画検討のために実施さ れている水理模型実験では, 流砂量計測は流砂を直接採 取計量することにより行われており, 計測箇所もサイフ オンを用いた浮遊砂の採取計測のほがはもつぱら水路下 流端での夕行われている現状にある. このような直接採 取による計測方法では，時間的な流砂量変化が激しい場
合や実験が長時間にわたる場合多大な労力を要する上, 模型の任意の断面における掃流砂量計測ができないとい った問題がある.

そこで，筆者等は模型実験における流砂量計測の簡素 化と任意断面における流砂量の計測を目的として，M ドロフォン流砂計測法の水理模型実験への適用について 検討を行っている. 本論では, まず, ハイドロフォンの 形状の違いによるカウントされるパルス数の違いについ て, および途中断面での流砂量計測を想定したスリット 急縮部での流砂量のカウント数一の応答特性について, それぞれ直線矩形水路を用いて行った基礎的な実駼結果 について述べる. 次に, 模型水路下流端にハイドロフォ ンを設置し，從来の土砂採取による流砂量計測結果との 比較を行い，水理模型実験一の適用可能性について考察 する. 


\section{2. ハイドロフォン流砂計測装置の概要}

今回使用したハイドロフォン流砂計測装置のシステム 構成を図-1に示す. 基本的には水山ら ${ }^{4)}$ が現地において 設置しているシステムと同じである. なお，今回の実験 ではパルス数の計数時間は 5 秒間としており，用いたデ 一ターロガーでは最大約 11 時間連続記録が可能である.

実験に用いたハイドロフォンン（金属管）の断面形状は 表-2 に示寸ように, 断面形状が円形 (外径 $27.2 \mathrm{~mm}$, 内 径 $25.2 \mathrm{~mm}$ ), 正方形 (外寸 $16 \mathrm{~mm} \times 16 \mathrm{~mm}$, 内寸 $13.6 \mathrm{~mm}$ $\times 13.6 \mathrm{~mm}$ ), 長方形 (外寸 $10 \mathrm{~mm} \times 22 \mathrm{~mm}$, 内寸 $7.6 \mathrm{~mm} \times 19.6$ $\mathrm{mm})$ の 3 種類である.管の長さはすべて $1 \mathrm{~m}$ である.なお, 円形断面のハイドロフォンには $1 \mathrm{~m}$ の直管の片方の端に 直角に円管を継ぎ足して L 字形をしたものも作成してい る. 特に, 急縮部での実験と模型実験には L 字形のハイ ドロフォンが用いられている. マイクロフォンは管内の 一方の端に，L 字形の場合は継ぎ足した方の端に配置さ れている. 写真-1 に模型実験でのハイドロフォンの設置 状況を示寸.

マイクロフォンから得られる信号は4段階の倍率 (ch1 〜 ch4)に増幅され円周方向の固有振動数に対応する $8 \mathrm{kHz}$ のバンドパスフィルターを通した後包絡線検波され，そ の振幅がchによらず一定に設定された敷居值を越えると きにパルスとして計数し記録される. 表-1 に増幅倍率を 示すように, 各 ch の増幅倍率の組み合わせはあらかじめ 3 通りに設定されており, それぞれ ch1 の増幅倍率を用い て感度 1-3 と呼ぶ. 表-1 の值は, 各感度, 各 ch の増幅 倍率を示している

\section{3. 実験概要}

\section{（1）直線矩形水路実験}

実験に用いた直線矩形水路は可変勾配，幅 $1.0 \mathrm{~m}$ ，長さ $20 \mathrm{~m}$ である. 水路床は粒径 $2.0 \mathrm{~mm}$ の一様砂を貼り付けた 粗面固定床である. 実験ケースを表-2 に示す. No.1〜 No.18 までは流量一定で 5 分間通水し, 上流端から給砂を

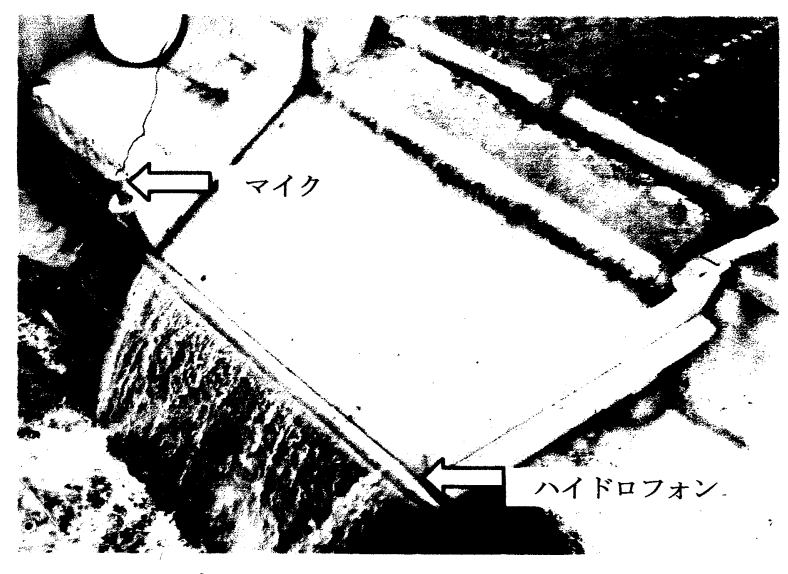

写真-1 ハイドロフォンの設置状況

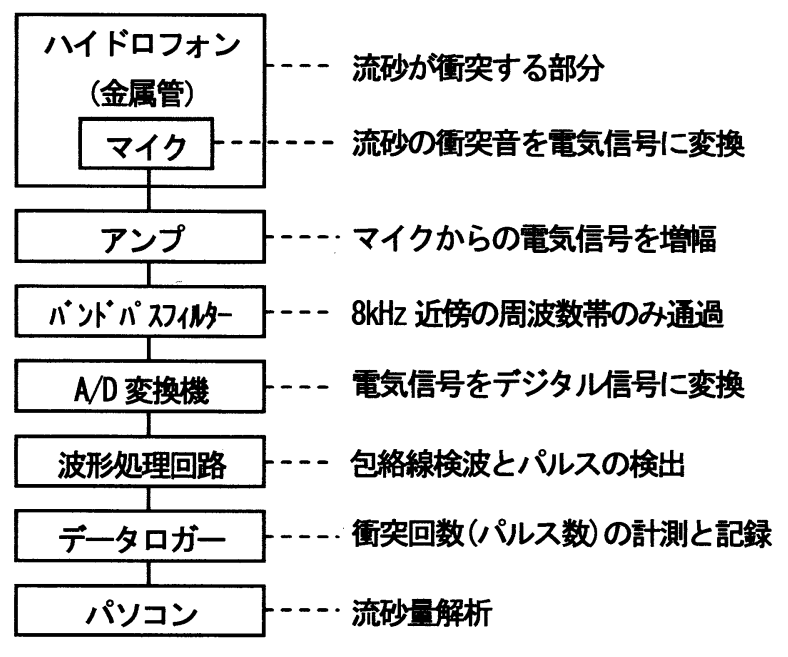

図-1 Mドロフォンのシステム構成

表-1 アンプの倍率設定とチャンネルの関係

\begin{tabular}{|c|c|c|c|c|}
\hline 感度 & ch1 & ch2 & ch3 & ch4 \\
\hline \hline 1 & 1.0 & 4.7 & 22.1 & 103.8 \\
\hline 3 & 3.0 & 7.1 & 16.6 & 38.9 \\
\hline 5 & 5.0 & 11.8 & 27.6 & 64.9 \\
\hline
\end{tabular}

表-2 矩形水路実験の条件一覧表

\begin{tabular}{|c|c|c|c|c|c|}
\hline No & 実験 & $\begin{array}{c}\text { 金属管断面形状 } \\
\text { 寸法は外寸寸 }\end{array}$ & 実験砂 & $\begin{array}{l}\text { 流量 } \\
\ell / \mathrm{s}\end{array}$ & 感度 \\
\hline 1 & \multirow{6}{*}{$\begin{array}{l}\text { 金属管の } \\
\text { 形状の運 } \\
\text { いに関す } \\
\text { る夷験 }\end{array}$} & \multirow{2}{*}{$\begin{array}{c}\text { 長方形 } \\
10 \mathrm{~mm} \times 22 \mathrm{~mm} \times 1 \mathrm{~m}\end{array}$} & \multirow{12}{*}{$\begin{array}{l}\text { 一様砂 } \\
\text { 粒径 } \\
2.0 \mathrm{~mm}\end{array}$} & 10 & 3 \\
\hline 2 & & & & 10 & 5 \\
\hline 3 & & \multirow{4}{*}{$\begin{array}{c}\text { 正方形 } \\
16 \mathrm{~mm} \times 16 \mathrm{~mm} \times 1 \mathrm{~m} \\
\text { P形直管 } \\
\text { 直径 } 27.2 \mathrm{~mm} \times 1 \mathrm{~m} \\
\end{array}$} & & 10 & 3 \\
\hline 4 & & & & 10 & 5 \\
\hline 5 & & & & 10 & 3 \\
\hline 6 & & & & 10 & 5 \\
\hline 7 & \multirow{12}{*}{$\begin{array}{l}\text { 砂の違い } \\
\text { に関する } \\
\text { 実験 }\end{array}$} & \multirow{14}{*}{$\begin{array}{c}\text { P形 } L \text { 型 } \\
\text { 直径 } 27.2 \mathrm{~m} \times 1 \mathrm{~m}\end{array}$} & & 10 & 3 \\
\hline 8 & & & & 10 & 5 \\
\hline 9 & & & & 5 & 3 \\
\hline 10 & & & & 5 & 5 \\
\hline 11 & & & & 20 & 3 \\
\hline 12 & & & & 20 & 5 \\
\hline 13 & & & \multirow{8}{*}{$\begin{array}{l}\text { 混合砂 } \\
\cdot \\
\text { 平均粒 } \\
\text { 径 } \\
\text { 2. Onm }\end{array}$} & 5 & 3 \\
\hline 14 & & & & 5 & 5 \\
\hline 15 & & & & 20 & 3 \\
\hline 16 & & & & 20 & 5 \\
\hline 17 & & & & 10 & 3 \\
\hline 18 & & & & 10 & 5 \\
\hline 19 & \multirow{2}{*}{ 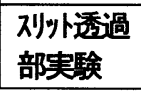 } & & & - & 3 \\
\hline 20 & & & & - & 5 \\
\hline
\end{tabular}

行っている. 流量は表-2に示すように 3 種類で, 給砂総

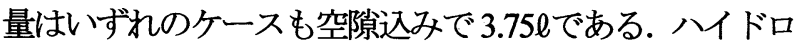
フォンは水路下流端に接続する斜路下流端に設置されて いる. また同時に水路下流端で流砂量を計測した.

No.19 とNo.20はスリット砂防えん堤の透過部を想定し た急縮部（幅 $4.8 \mathrm{~cm}$, 長さ $30 \mathrm{~cm}$ ）を水路下流端に設置し た実験で, ハイドロフォンは透過部上流端から $15 \mathrm{~cm}$ の位 
置に透過部を横断するように設置した. また，実験は， 土砂を急縮部の上流に敷いて（堆積部）急縮部上流端を 閉じて湛水させた後開き，自然流下による土砂流出の状 態で行い，同時に下流端で流砂量を計測した.

実験に使用した砂は，粒径 $2.0 \mathrm{~mm}$ の一様砂と，図-2に 示す粒度分布を持つ平均粒径 $2.0 \mathrm{~mm}$ の混合砂である.

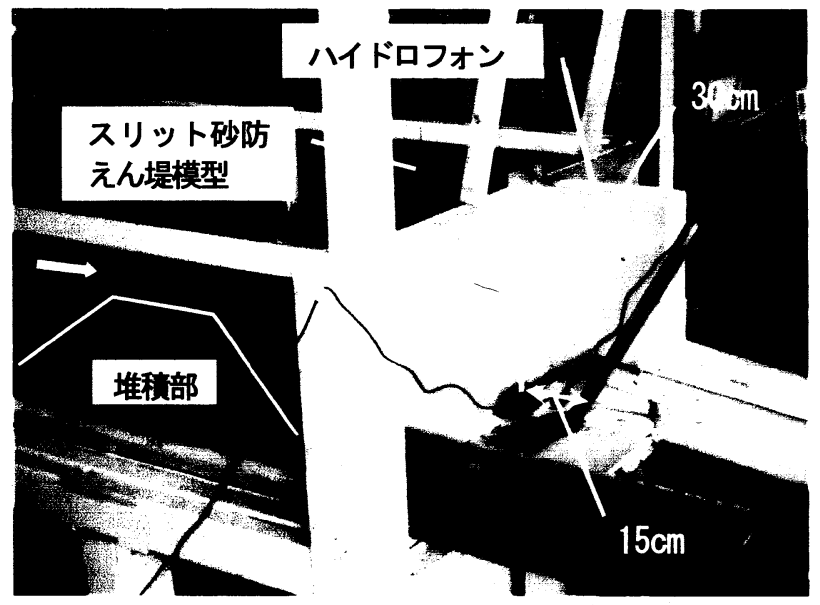

写真-2スリット透過部実験のスリット部の状況

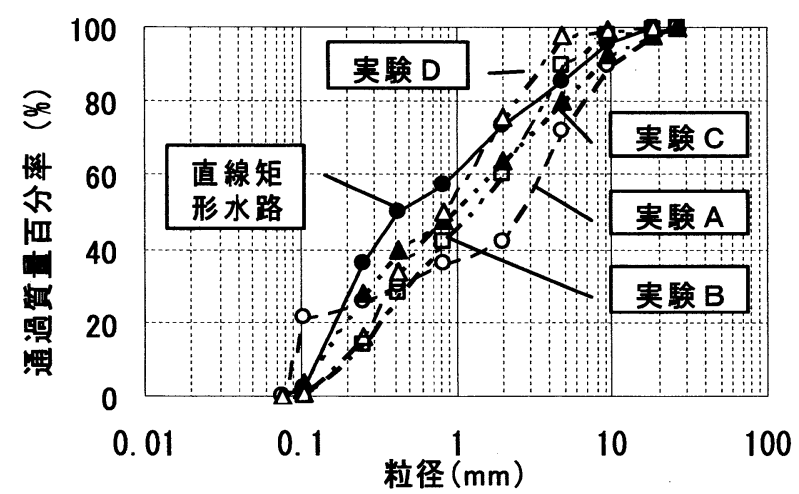

図-2 実験砂(混合砂)の粒度分布曲線

\section{（2）地形模型実験}

4 種類の模型実験（実験 $\mathrm{A} \sim \mathrm{D}$ ) でハイドロフォンによ る流砂量計測を実施した. それぞれの実験に用いた流砂 の粒度分布を図一2に示す。

実験 $\mathrm{A} ・ \mathrm{~B} ・ \mathrm{C}$ は洪水を対象とした実験であり流量が時 間的に変化するが実験 D は流量の時間的変化はない，な お, 実験 $\mathrm{A}$ は同一の洪水波形を 2 回続けており， 1 波形 目の実験を A-1，2波形目の実験を A-2 と呼ぶ. 模型下 流端では 3ー5 分間隔で流砂量を計測している.

\section{4. 計測結果と考察}

(1) 直線矩形水路実験

a)ハイドロフォンの形状の違いよる流砂量とパルス数の 応答性

No.1ーNo.6 の実験ケースのうち No.1,3,5（感度 3）では すべてのch でパルスが計数されなかった. ほかの実験ケ 一スでは，一般にそのケースに特有のch でのみパルスが 得られている. なお, No.5 とほぼ同じ条件と考えられる No.7 (円形L 型) ではパルスがカウントされている.

No.7で得られたパルスが No.5 で得られなかったのは No.5 が直管であるためこの実験条件では管内の残響が大 きく振幅が常に飽和していたからではないかと推定して いる. また, No.1,3 でパルスが得られなかったのは，八 イドロフォンに用いた管の厚さが円形のそれに比べて $0.2 \mathrm{~mm}$ 厚いため衝突音の音圧が小さかったことと, フィ ルターの周波数が形状に合っていなかったため最終的に 得られる振幅が小さく敷居值を越えられなかったためで はないかと推定している.

そこでパルスが良好に得られた No.2,4,6,8（感度 5）を 対象として形状の違いによるパルス数の時間変化を比較 する. パルスが得られたch は形状により異なるため, こ こでは No.2,4,6 は ch4, No.8 は ch3 の Pulse 数の比較を No.8の流砂量とともに図-3に示す.

図-3 より，No.2,8（長方形と円形L型）は全計測時間 （300 秒）にわたりパルスが良好に得られている. また， ch の違いによるパルス数の絶対值に差はあるものの, パ ルス数の時間変化の傾向はよく似ている. №.6（円形直 管）はパルス数が 15〜20を越すとそのすぐ後にパルス数 が急减する傾向が示されている. また, No.4 (正方形) は計測時間 (300 秒) を通じてパルス数が 4 以下であり流 砂量変換の精度が悪いことが推定され，この実験条件の もとでは流砂量測定には使用できないと思われる.

これらの結果からは, 今回の実験に用いたハイドロフ オンの中では円形 $\mathrm{L}$ 型か長方形が良いと考えられるが, バンドパス周波数との関係も含めハイドロフォンの形状 についてはさらに検討する必要がある. 特に設置する場 所によっては直管の使用も大いに考えられるため直管と $\mathrm{L}$ 型管の特性の違いについてはより詳しく検討する必要 がある.

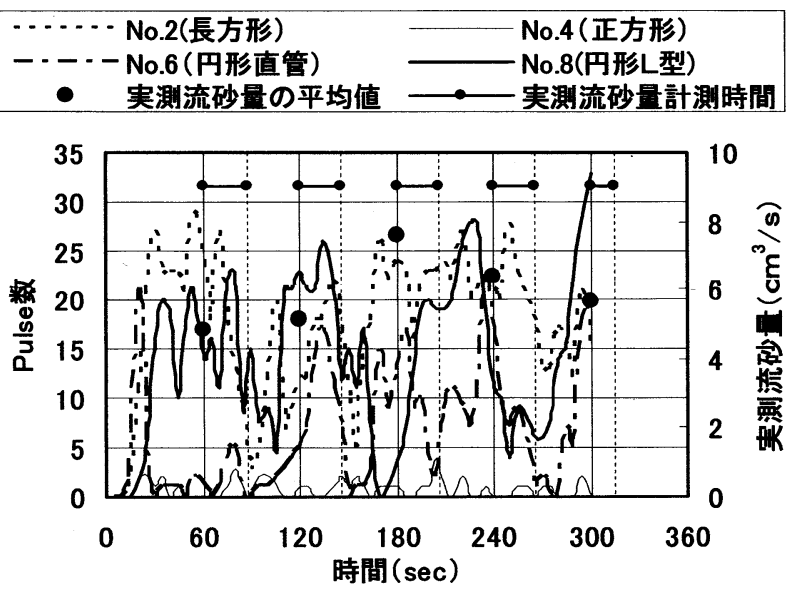

図-3 No.2,4,6,8 のパルス数と No.8 の流砂量の時間変化 


\section{b）一様砂と混合砂の違いによる流砂量とパルス数の応 答性}

円形 $\mathrm{L}$ 型のハイドロフォンを使用した場合の一様砂と 混合砂のパルス数とについて, 流量を変えて比較し, 流 砂量の実測值とともに図-4 6に示寸. 比較に使用する感 度, ch は同一のものを使用したが, 流量 200/s の場合は, 混合砂における感度 5 の ch4 でパルスが得られなかった ため ch3 のそれと比較した. また, 混合砂の場合, 複数 の感度と ch でパルスを得られている. 各図中の波線は, 通水時間全体を通して最もパルス数が多いケース（感 度・ch）を破線で示した.

図-4 は流量 5.08/s の場合を示すが，パルスの応答開始 時間についてみると, どのchでも混合砂の場合には通水 開始加約 30 秒後，一様砂の場合通水開始加ら約 50 秒 後となっている. この時間は図 $-5,6$ との比較から分かる ように流量が多くなるにつれて短くなっている.

またこれらの図からパルスの応答が顕著となってから のパルス数の時間変化の傾向は, $5.0 \mathrm{l} / \mathrm{s}$ の場合を除いて一 様砂の場合も混合砂の場合もほぼ同じであることが分か る. これは掃流力の増大により粒径別流砂から限界掃流 力の影響にあまり差がなくなったことによるものであろ うと推定している. またパルス数の時間変動は一様砂 (図 中の太い実線）のほうが大きいことから，混合砂よりも 一様砂で流砂量の時間変動が大きいと推定することがで きるが，実測流砂量からは得られている值がパルス数の 計数時間よりはるかに長い時間の平均值であるためここ でその問題について議論することはできない.

図-4の流量 5.00/s の場合, 通水後半, $200 \mathrm{sec}$ 以降にお いて, 混合砂の実験における感度 $3 \cdot \mathrm{ch} 4$ (No.13) の Pulse 数が 0 に近くなるため同一感度・ch である No.9 との比較 ができなくなる. しかし，混合砂で Pulse 数の合計数が多 いケース（No.13 の感度 $3 \cdot \mathrm{ch} 3)$ との比較を行うと, 一 様砂とほほ同じ傾向をもつことが分かる．また，混合砂 の実測値との比較から, No.13の ch3 は実測流砂量の時間 変化と傾向がほぼ一致していることが分かる.

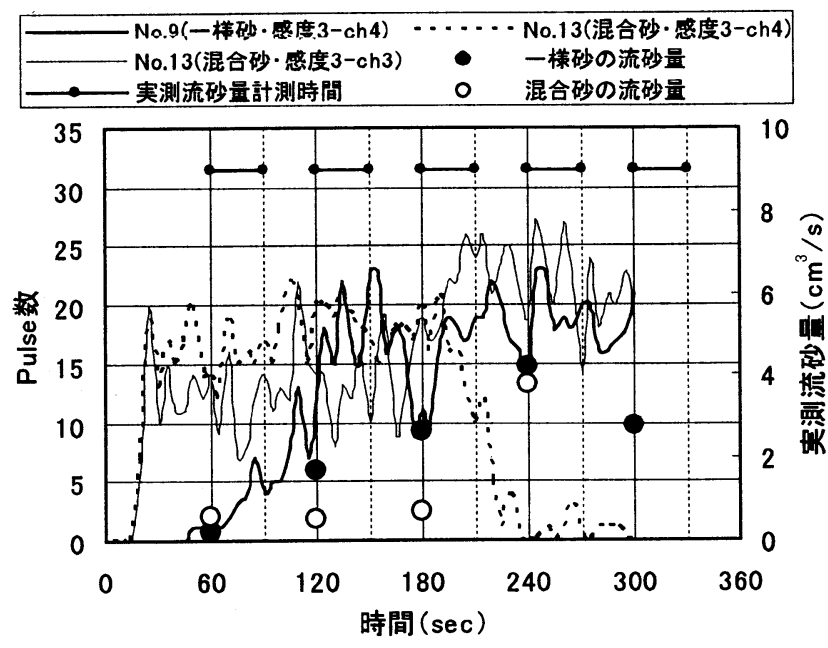

図-4 Pulse 数と実測流砂量の時間変化（流量 $5.0 \ell / \mathrm{s}$ ）
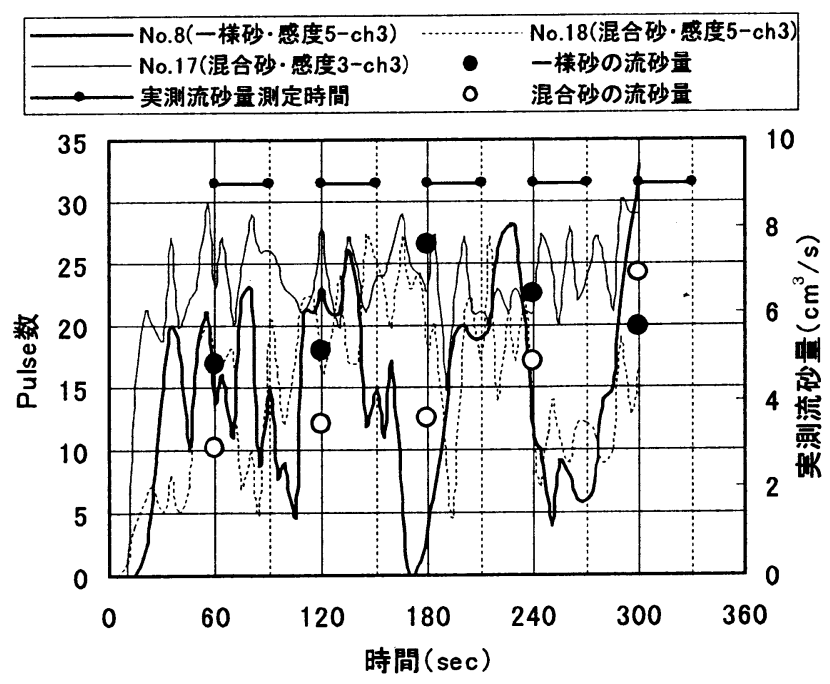

図-5 Pulse 数と実測流砂量の時間変化（流量 $10.0 \ell / \mathrm{s}$ )

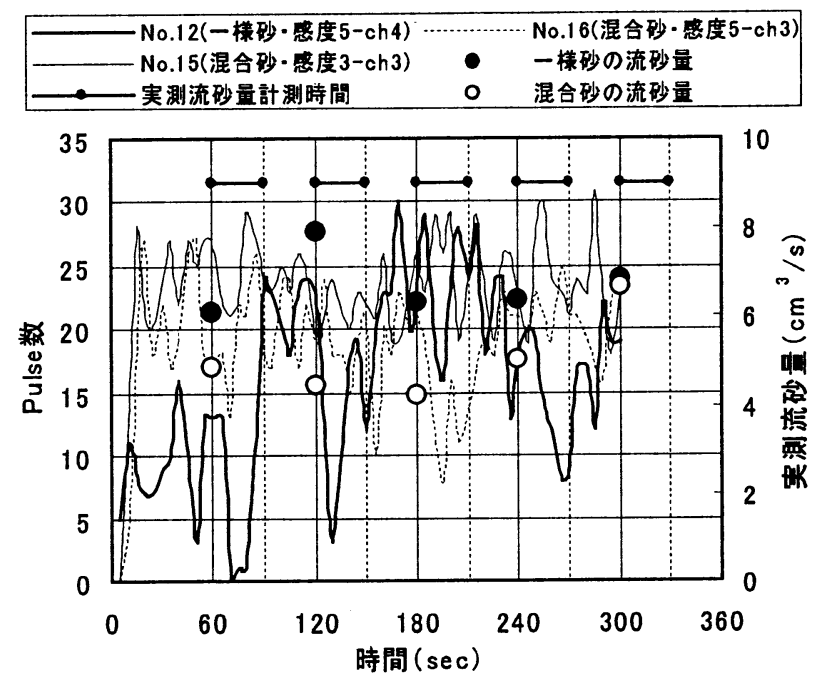

図-6 Pulse数と実測流砂量の時間変化（流量 $20.0 \ell / \mathrm{s}$ )

\section{c)急縮部を通過する流砂量とパルス数の応答性}

図-7に No.19，20 の実験結果を示す. パルス数の時間 的変化と実測流砂量の時間変化はほぼ一致しており, ピ 一ク時の土砂濃度 (1.9\%) 程度であれば八イドロフォン による流砂量への恋換には問題が無いものと考えられる.

急縮部を通過する流砂量は 120sec から 150sec にかけ て最大となる.この流砂量のピーク時に，砂はある流動 層厚で持って急縮部を流下寸ると考えられる. そこで, ピーク時の単位時間当たりの実測流量 $\left(5,060 \mathrm{~cm}^{3} / \mathrm{s}\right)$ を用 いて移動している砂の層の厚さを式(1)より求めた ${ }^{9)}$.

$$
\frac{C_{s} h_{s}}{d}=\frac{1}{\mu_{f}}\left(\tau_{*}-\tau_{*_{c}}\right)
$$

ここに, $C_{s}$ は移動層の平均濃度 (0.3 とした.),$d$ は砂 の径, $h_{s}$ は移動層の厚さ, $\mu_{f}$ は砂粒子の動摩擦倸数 (0.675 とした.)， $\tau_{*}$ は無次元掃流力, $\tau_{*_{c}}$ は無次元限 界掃流力である. その結果, 流砂の層厚は $0.5 \mathrm{~cm}$ と得ら れ，スリット底面に設置した金属管の突出高さ， $0.5 \mathrm{~cm}$ 
と同程度であることになり十分計測に使用できると考え られる.

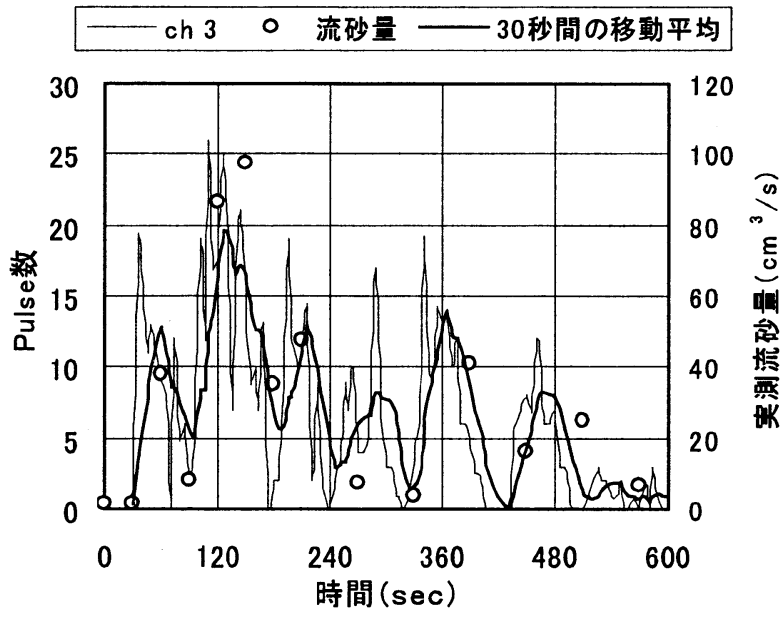

図-7 スリット部からの流砂によるPulse 数と実測流砂量

\section{(2) 模型実験}

a) 模型下流端における流砂量と Pulse 数の応答性

図-8,9 亿代表的なパルス数とその時の実測流砂量の時 間変化の比較図を示す. 図中には流量波形も示した. 使 用した増幅率は感度 $1 \cdot \operatorname{ch} 3$ である. 図-8（実験 $\mathrm{A}-1$ ) より, 実測流砂量とパルス数の時間変化の傾向, 並びに ピークの時刻がほぼ一致しており，流砂量変化に対する パルス数の応答性は良好であることが示されている.

図-9（実験C）は実測流砂量がピークとなる時期にお いてパルス数が減少している.これは，ピーク前後にお いては流量が多いため金属管に衝突する砂の速度が増加 し，また，流出する砂の粒径も大きくなるため衝突音が 大きくなり， ハイドロフォン内での残響音が長く残るた め，その間のパルスが得られなくなったためであると推 定している.

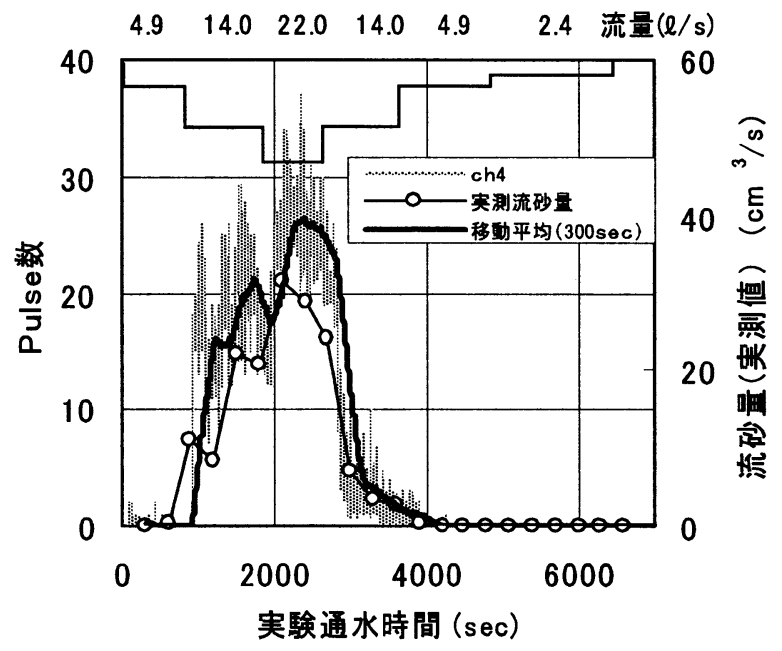

図-8 Pulse 数と流砂量の比較（実験A-1）
図-10に, 実験A - 1の ch3における各実測流砂量採取 時と同じ時刻に記録したPulse 数との関係を示す. Pulse 数の流砂量に対する関係はほぼ比例していることが分か る.

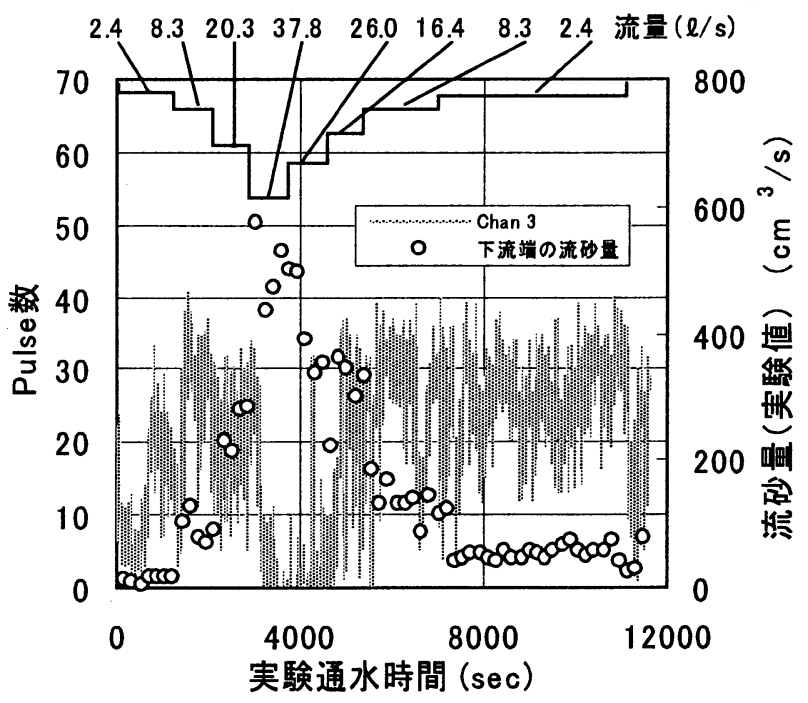

図-9 Pulse数と流砂量の比較 (実験C)

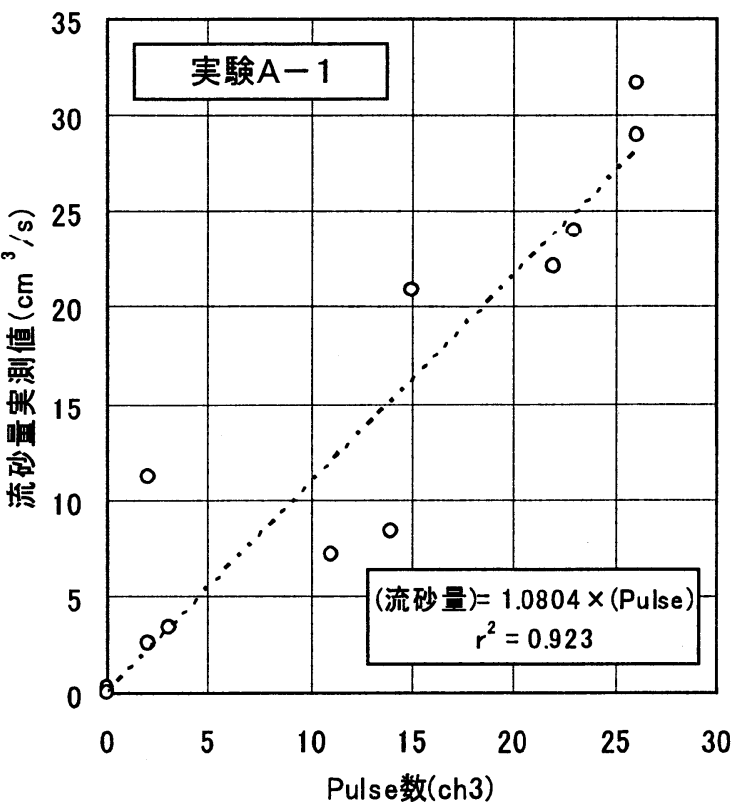

図-10 Pulse 数と実浿流砂量の関係（実験A-1）

\section{b)Pulse 数の合計数と総流出土砂量の関係}

図-11にch3で記録したPulse数の合計数と実測による 総流出土砂量の関係を示寸. Pulse 数の合計数と総流出土 砂量はほぼ比例している. なお, 実験Cは図-9に示すよ うに実測流砂量のピーク時において Pulse 数が極端に減 少するためこの図からは除いた。 


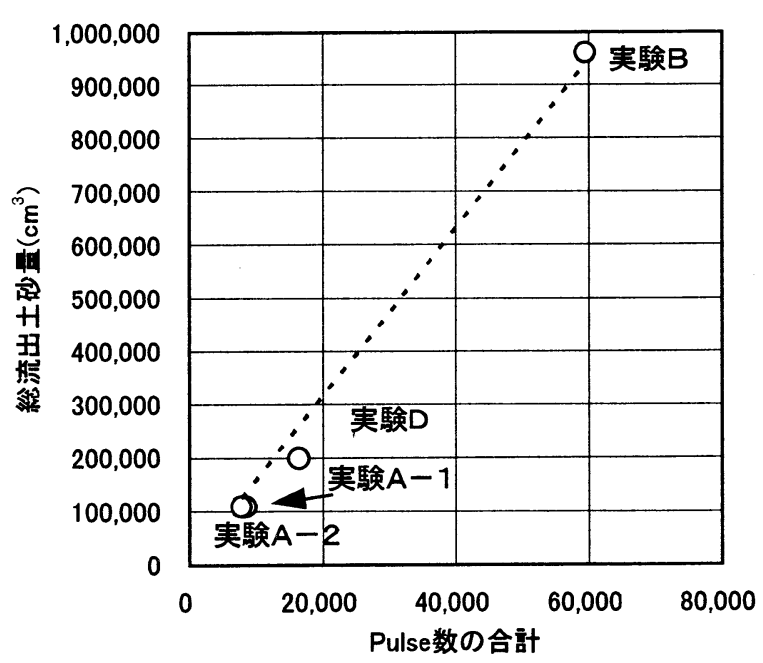

図-11 Pulse 数の合計と実測総流砂量の関係

\section{5. おわりに}

ハイドロフォンを実験に使用し, Pulse 数と実測流砂量 の相関が良好であることが示され，今後の水理模型実験 における流砂量計測の簡素化・省力化の可能性が示され た.

また，金属管の断面形状の違いによる Pulse 数の時間 変化,一様砂と混合砂の違いによるPulse数の時間変化, スリット部のハイドロフォンによる流砂量計測の可能性 について検討した. その結果, 以下の事項が分かった.

(1)今回の実験の範囲では流砂量計測に使用する金属管の 形状としては長方形か双形L型が良いと考えられる.

(2)一様砂も混合砂も平均粒径が同じであれば，ハイドロ フォンから得られるパルス数に大きな違いは無い! 一様 砂ではパルスが得られる感度・ch に制限があるが，混 合粒径ではパルスが得られる感度・ch が広い.また, パルス数の応答開始時間については流量が少ないほど 一様砂の方ほど長くなる傾向が示された.

(3)スリット部におけるパルス数と実測流砂量の時間变化 はほぼ一致し, 実験の範囲におけるピーク時の土砂濃 度（1.9\%）程度であればハイドロフォンによるパルス 数と流砂量との相関は高い.
Pulse 数から流砂量を推定する精度の向上のためには, 流砂量が増加した場合でも確実に衝突音を採取できるよ うな感度の設定と，直管を使用した場合に見られたパル スの応答性低下に対する工夫が必要と考えられる.

最後に，今まで地形模型実験による混合砂を対象とし た実験においては, パルス数はほぼ各chで採取されてい たが，一様砂を対象とした実験ではパルス数を採取でき た ch が感度 3 と 5 とも $4 \mathrm{ch}$ ののケースが多く，9ケー ス中 7 ケースを占めていたことを記しておきたい：これ は，一様砂では粒径に対して卓越する感度と ch があり， それらを解析する事が出来れば流砂量の粒度分布の推定 も可能であると考えられる.

\section{参考文献}

1) 栗原淳一，宮本邦明 : 音響を利用した流砂量計測装置につい て, 砂防学会誌, Vol.44, No.5, pp.26-31, 1992.

2) 桑村貴志, 財津知亭, 市川嘉稫, 齊藤大作, 若林英樹, 原田輝 雄: 石狩川における流砂の計測, 砂防学会誌、Vol.54, No.5, pp.86-91, 2002.

3) 浦真, 下井田実, 有澤俊治, 村松道康, 植野利康, 横山康二, 浜 名秀治: 与田切川における土砂流出モニタリングについて (そ の1), 平成 13 年度础防学会研究発表会概要集, pp.308-309, 2001.

4) Christoph Hegg, Dieter Ricknmann : Short-time relations between runoff and bed load transport in a steep mountain torrent, Modeling Soil Erosion, Sediment Transport and Closely Related Hydrological Processes, IAHS Publ. no. 249, pp.317324, 1998.

5)澤井健二 : 流砂計測技術の現状と展望，砂防学会誌，V61.54， No.2, pp.75-84, 2001.

6)水山高久, 野中理伸, 野中伸久: 音響法 (ハドロフォン) に よる流砂量の連続計測, 砂防学会誌, Vol.49, No.4, pp.34-37, 1996.

7)高濱崞一郎，渡部文人，右近則男，安養寺信夫 : 音響法による 流砂計測, 砂防学会誌、V61.54, No.6, pp.59-63, 2002.

8) 水山高久, 野中理伸, 藤田正治: 常願寺川津之浦下流砂防堰堤 に执けろハドロフォンによる流砂観測, 砂防学会誌，V61.55, No.3, pp.56-59, 2002.

9)伊藤隆郭, 江頭隹治: 流砂量に及ぼす砂粒子径の影響, 水工学 論文集, 第45 巻, pp.649-654, 2001.

(2003.9. 30 受付) 